\title{
Building a Capital Markets Union: Improving the Market Infrastructure
}

\author{
Eva Micheler ${ }^{1}$
}

Published online: 28 November 2016

(C) The Author(s) 2016. This article is published with open access at Springerlink.com

\begin{abstract}
The European Commission has recently launched a new project intended to create a Capital Markets Union. One obstacle in the way of the Commission's vision is the current market infrastructure for holding securities. This infrastructure is inefficient because it prevents investors from exercising voting rights and from claiming against issuers. It also exposes investors to the risk of shortfalls, which increases with the number of custodians that operate between issuers and investors. This article also shows that the regulatory regime as it stands fails to remedy this inefficiency or to contain the risk. It points to possible avenues for law reform but concludes that these, too, are unlikely to improve the situation. The conclusion is that investors should receive information about the identity of all sub-custodians that operate between them and the issuer and about their terms.
\end{abstract}

Keywords Capital Markets Union - Custodian · Securities · Settlement - Client assets - MiFID - Custody - Depositories - Central securities depositories · Target 2 securities

\section{Introduction}

The European Commission has recently launched a new project intended to create a Capital Markets Union (Sect. 2). One obstacle in the way of the Commission's vision is the current market infrastructure for holding securities (Sect. 3). This infrastructure is inefficient because it prevents investors from exercising voting rights and from claiming against issuers (Sect. 4). It also exposes investors to the

Eva Micheler : Associate Professor (Reader).

Eva Micheler

E.Micheler@1se.ac.uk

1 London School of Economics and Political Science, London, UK 
risk of shortfalls, which increases with the number of custodians that operate between issuers and investors (Sect. 5). The analysis in Sects. 5 and 6 also shows that the regulatory regime as it stands fails to remedy this inefficiency or to contain the risk. It points to possible avenues for law reform but concludes that these, too, are unlikely to improve the situation.

The European Central Bank has recently started an IT project entitled 'Target 2 Securities' (T2S) (Sect. 6). The hope is that the platform will provide custodians with a framework within which they compete with each other. Competition then can lead to a leaner and more efficient infrastructure. This paper argues that the T2S project only creates a further layer of complexity. Moreover, a new computer programme does not put in place an incentive for custodians to engage in competition.

The conclusion of the paper is that investors should receive disclosure about the identity of all sub-custodians and their terms (Sects. 7 and 8).

\section{The Vision}

On 18 February 2015, the European Commission published the Green Paper on Building a Capital Markets Union. ${ }^{1}$ The Commission observed that, compared to other parts of the world, European businesses remain heavily reliant on banks for funding and relatively less so on capital markets. ${ }^{2}$ After the financial crises, bank funding dried up and recent regulatory reforms have made it more difficult for banks to take on debt.

The Commission would like to unlock more investment for all companies by attracting investors from the rest of the world to the EU and by persuading the citizens of Europe to take their money out of bank deposits and real estate and invest it in European businesses and infrastructure projects.

To facilitate this, the Commission believes it needs to identify and remove barriers which stand between investors' money and investment opportunities. The system for channelling funds - the investment chain - needs to be made as efficient as possible, both nationally and across borders.

The Commission intends to build a single market for capital from the bottom up, identifying barriers and knocking them down one by one, creating a sense of momentum and helping to spark a growing sense of confidence in investing in Europe's future. The free flow of capital was one of the fundamental principles upon which the EU was built. More than fifty years on from the Treaty of Rome, the Commission would like to seize the opportunity to turn that vision into reality. ${ }^{3}$

\footnotetext{
${ }^{1}$ European Commission, Green Paper: Building a Capital Markets Union, Brussels 18 Feb 2015 COM(2015)63 final (CMU Green Paper), available at http://ec.europa.eu/finance/consultations/2015/ capital-markets-union/index_en.htm (last accessed 9 Sept 2016).

2 CMU Green Paper, supra n. 1, at p. 2; see also Commission Staff Working Document, Economic Analysis accompanying the document Communication from the Commission to the European Parliament, the Council, the European Economic and Social Committee and the Committee of the Regions: Action Plan on Building a Capital Markets Union, Brussels 30 September 2015 (CMU Economic Analysis), available at http://ec.europa.eu/finance/capital-markets-union/docs/building-cmu-economic-analysis_en. pdf (last accessed 9 Sept 2016).
}

3 CMU Green Paper, supra n. 1, at p. 3. 


\section{Securities Law as a Barrier}

Having stated its vision, the Commission then identifies and analyses a number of barriers that stand in the way of and invites contributions on how these could be removed. One of the barriers mentioned is the market infrastructure and securities law. The Commission points out that the 'piping' which channels investments and the laws under which it is treated are key determinants of the efficiency and ease by which investment can be made. ${ }^{4}$

The Staff Working Document supporting the Green Paper mentions that the US securities markets are underpinned by only two central securities depositories (CSDs). European securities are, by contrast, not held in one but in a range of CSDs in different countries. Investors may need to rely on additional intermediaries to access markets outside their own jurisdiction. They will have to go through international CSDs and global and local custodians.

The structure of a custody chain can be illustrated as follows:

Investor

Domestic retail custodian

Domestic wholesale custodian

Global custodian

CSD

Issuer

The characteristic feature of a custody chain that operates across borders is that there is no direct connection between the issuer and the investor. The investor has a relationship with a domestic retail custodian. That custodian has a relationship with a domestic wholesale custodian, who has a relationship with a global custodian, who has another relationship with a CSD. The CSD is connected with the issuer.

Custody chains create a barrier to investment. They introduce significant operational risks and costs. Investors who hold securities are exposed to the risk of the issuer defaulting. This risk applies notwithstanding how securities are held. When securities are held through a chain of custodians, investors are saddled with additional risk. A custody chain can make it impossible for investors to exercise voting rights ${ }^{5}$ or to claim against the issuer (Sect. 4). Custody chains also expose the investor to the risk that any of the custodians forming the chain do not have sufficient securities to meet the investor's claim (Sect. 5).

The issue is complex as it touches on property, contract, corporate and insolvency law, as well as on the laws on holding of securities and conflict of laws. ${ }^{6}$

\footnotetext{
${ }^{4}$ Ibid., at p. 23; CMU Staff Working Document, infra n. 5, at p. 15; see also Communication from the Commission, Action Plan on Building a Capital Markets Union, COM(2015) 468 final, Brussels, 30.9.2015 (CMU Action Plan), at pp. 23-24, available at http://ec.europa.eu/finance/capital-marketsunion/docs/building-cmu-action-plan_en.pdf (last accessed 9 Sept 2016).

5 Commission Staff Working Document, Initial reflections on the obstacles to the development of deep and integrated EU capital markets, accompanying the document Green Paper: Building a Capital Market Union, Brussels 18 Feb 2015, COM(2015)63 final (CMU Staff Document), at p. 13, available at http:// eur-lex.europa.eu/legal-content/EN/TXT/?uri=CELEX\%3A52015SC0013 (last accessed 9 Sept 2016).

${ }^{6}$ CMU Green Paper, supra n. 1, at p. 23.
} 
The Staff Working Document adds that the subject is also politically sensitive, with discussions dating back more than a decade. ${ }^{7}$

There are two views on how to proceed. According to one view, there is potential to make further improvements to the market infrastructure through European legislation. Legislation relating to investors' rights in securities differs amongst Member States.

According to a different view, no legislation is required because the Target 2 Securities project, which was launched on 22 June 2015, will remove the legal and operational risks associated with the transfer and holding of securities across jurisdictions and reduce costs, and it could increase cross-border investments.

This article first illustrates inefficiencies that trouble a market infrastructure that is built on custody chains (Sects. 4, 5). It concludes that neither of the abovementioned options is likely to create an efficient market infrastructure. Against the background of an infrastructure that connects custodians through bilateral contracts, there is not much the law can do. Moreover, custodians have no incentive to compete with each other. Target 2 Securities and the Central Securities Depositories Regulation are unlikely to change that (Sect. 6). Investors should be given disclosure about sub-custodians and their terms, enabling them to kick-start a process that leads to a more efficient system (Sects. 7, 8).

\section{Exercising and Enforcing Rights Against Issuers}

\subsection{Voting Rights}

The European Commission points out that custody chains can make it difficult for investors to exercise voting rights. ${ }^{8}$ This is supported by empirical evidence showing that logistics involved in processing voting instructions in custody chains prevent votes from reaching issuers. ${ }^{9}$ Notwithstanding the available technology, passing along voting rights through a chain has proven to be very difficult. ${ }^{10}$ Custodians normally outsource the processing of voting instructions to proxy advisors. ${ }^{11}$ These providers need to process these instructions and set deadlines that are 7-10 days before the meeting. ${ }^{12}$ If an investor sells shares after that deadline but before the deadline for sending votes to the issuer, it is possible that the seller's

\footnotetext{
7 CMU Staff Working Document, supra n. 5, at p. 15.

8 Ibid., at p. 13.

9 Company Law Review Final Report I, para. 6.25. See also Review of the Impediments to Voting UK Shares, Report by Paul Myners to the Shareholder Voting Working Group, July 2007, at pp. 1-4, and Report of the Committee of Inquiry into UK Vote Execution, on behalf of the National Association of Pension Funds, July 1999, para. 1.7; see also Zetzsche (2008), at p. 327, and Strenger and Zetzsche (2013), at pp. 517-522.

${ }^{10}$ See also Zetzsche (2008), at p. 333, and Kahan and Rock (2007).

11 Manifest (2007), at p. 3.

12 Custodians sometimes also block shares in order to be able to process voting instructions, European Commission, Directorate General Internal Market and Services, Summary of the Informal Discussion Concerning the Initiative on Shareholders Engagement (March 2013), at p. 6.
} 
instructions cannot be cancelled in time and that the buyer's instructions have nevertheless reached the issuer. In these circumstances the company will receive more votes than shares. The company does not have access to the records of the proxy advisors or of the custodians forming the chain. It is therefore unable to determine which votes to accept. If there is doubt as to whether a vote was validly cast, the company will disregard that vote. ${ }^{13}$ Problems are exacerbated by omnibus accounts. The service providers concerned need to determine what proportion has abstained or has voted for or against on every resolution. If the shares are held through more than one custodian, this process has to be repeated at every level. If shares are sold during that period, voting instructions need to be withdrawn and reissued. There is a view that in these circumstances accurate reconciliation of holdings is next to impossible. ${ }^{14}$ If an issuer receives more voting instructions for an omnibus account than shares held in the name on the register, there is a risk that all votes cast in relation to that registered name will be disregarded. If the name registered on the shareholder register relates to an omnibus account, this can, apparently, lead to the registrar having to disregard the votes for as much as $10 \%$ of the shares on the register. ${ }^{15}$

\subsection{Enforcement of Rights}

It has been shown elsewhere that custody chains can make the enforcement of rights next to impossible. ${ }^{16}$ There are two recent UK High Court cases where investors were prevented by a custody chain that operated between them and the issuer from enforcing rights. One case concerned German investors who failed to claim as shareholders of a UK-registered company whose shares were listed in Germany. ${ }^{17}$ The other case concerned an investor in bonds that were issued under English law and held through a custody chain involving Luxembourg. ${ }^{18}$ In both cases the reason for being unable to enforce rights was that the custody chain prevented the investor from having standing in a lawsuit against the issuer.

\subsection{Limitations of the Law}

There are two ways for the law to help here. One is to require custodians to pass on rights along the chain. The other option is to empower indirect investors, giving them a right to pierce through their custody chain irrespective of whether this is supported by the documentation that governs their immediate custody relationship or the relationships between the sub-custodians.

\footnotetext{
13 Manifest (2007), at p. 3.

14 Ibid., at p. 4; M van Esch (Robeco), 'Audit shows flaws in the proxy-voting process', 29 October 2012, available at http://www.robeco.com/en/professionals/insights/sustainability-investing/insights/2012/ audit-shows-flaws-in-the-proxy.jsp (last accessed 12 Jan 2016).

15 Manifest (2007), at p. 4; see also van Esch (Robeco), supra n. 14.

16 Micheler (2015).

17 Eckerle v Wickeder [2013] EWHC 68 (Ch) [2014] Ch 196.

18 Secure Capital SA v Credit Suisse AG [2015] EWHC 388 (Comm) 25 Feb 2015.
} 


\subsubsection{Requiring Custodians to Pass on Rights}

The law could impose a duty on custodians to pass on rights and information along the chain between issuers and investors. This approach underlies the recent Commission proposal for a new Shareholder Rights Directive (SRD II Proposal). ${ }^{19}$ The proposal aims to make it easier for shareholders to exercise voting rights. ${ }^{20}$ The rules proposed apply to equity securities only. Art. 3a requires Member States to ensure that intermediaries offer listed companies the possibility to have their shareholders identified. Upon a request of a listed company the intermediary shall communicate without delay to the company the name and contact details of shareholders. If there is more than one intermediary in a holding chain, the request of the company and the shareholder details shall be transmitted between intermediaries without undue delay. ${ }^{21}$ Member States may stipulate that CSDs are to be responsible for collecting the information and for providing it directly to the company. ${ }^{22}$ Member States also need to ensure that any intermediary that transmits this information will not, as a result of this, be in breach of contract or law.

If a listed company chooses not to directly communicate with shareholders, Member States need to ensure that information that is necessary for a shareholder to exercise rights flowing from his shares shall be transmitted by the intermediaries without undue delay. ${ }^{23}$ Member States shall also ensure that the intermediary facilitates the exercise of rights by shareholders, including the right to participate and vote in general meetings. ${ }^{24}$ The Commission has powers to adopt implementing acts to specify the requirements that need to be met by Member States.

The proposed Directive instructs custodians to pass on information. The information is communicated bilaterally from one custodian to the other. This does not improve the situation much. It is true that, at present, custodians can use terms that do not require them to facilitate the exercise of rights by investors. If the Commission succeeds in drafting appropriate implementing measures, using such terms should no longer be possible for custodians that are based within the reach of

\footnotetext{
19 Proposal for a Directive amending Directive 2007/36/EC as regards the encouragement of long-term shareholder engagement and Directive 2013/34/EC as regards certain elements of the corporate governance statement, COM(2014) 213, 2014/0121/COD, http://ec.europa.eu/prelex/detail_dossier_real. cfm?CL=en\&DosId=1041890 (accessed 9 Sept 2016) (SRD II Proposal); on 19 December 2014, the Committee on Legal Affairs published a draft report on the Commission's proposal suggesting amendments, http://www.europarl.europa.eu/sides/getDoc.do?type=COMPARL\&mode=XML\&language $=$ EN\&reference=PE544.471, accessed 9 Sept 2016 (SDR II Proposal Draft Report European Parliament).

20 SRD II Proposal, supra n. 19, at p. 5.

21 Ibid., Art. 3a(2).

22 SDR II Proposal Draft Report European Parliament, supra n. 19, Art. 3a(2), as amended.

23 Requiring custodians to assist with voting is a suggestion that can also be found in the literature: Zetzsche (2008), at p. 334, proposes to impose a duty on custodians to assist investors to vote and to prohibit custodians from charging fees for this. He also suggests that custodians should be encouraged to negotiate common technical standards and that the 'principle of proportionality' should be extended to custodians, but does not further explain what the principle of proportionality would imply in the circumstances. Note that a duty to exercise voting instructions already exists in English law: Kirby $v$ Wilinks [1929] 2 Ch 444.
}

24 SRD II Proposal, supra n. 19, Art. 3c. 
European rules. But that does not achieve much. The rules will merely instruct custodians to take part in a game of Chinese whispers where at each level there is potential for mistakes to occur.

Moreover, requiring custodians to facilitate the enforcement of claims against issuers is unlikely to create an efficient framework. It is impossible to manage litigation using communication that is channelled through a custody chain. The lawyers representing the investor would have to route every-even the most minor-procedural instruction through the custody chain to cause it to be executed by the custodian connected to the issuer.

A more effective option would be to introduce a requirement enabling the investor to collapse the chain. The investor would have a right to request delivery or assignment of the rights held by his custodian. Having stepped into the shoes of that custodian, he would then be entitled to request delivery/assignment of the rights held by the next custodian and continue along the chain until he is in the position of a direct investor.

Assuming law could be drafted to deliver this result in all European jurisdictions, the process would still be long-winded and time-consuming, significantly adding cost to the enforcement of claims against issuers.

\subsubsection{Empowering Indirect Investors}

Another option enabling investors to enforce rights against issuers would be to require issuers to recognise indirect investors. This is easier said than done. Issuers would have to be able to verify the identity of an indirect investor. ${ }^{25}$ They would not know who the custodians are that act between them and the investor. The identity and number of custodians also changes as securities are bought and sold. Even if no transactions occurred, custodians would be able to move securities between sub-custodians, and subcustodians would be able to delegate holdings to further sub-custodians. Issuers would have to request and investors would have to deliver verification starting from the CSD (or its sub-custodian) and then each custodian operating between them and the investor one after the other. This would be burdensome, time-consuming and costly.

\subsection{Conclusions}

The law is not able to do much. As long as the market infrastructure is organised through custody chains, significant friction will continue to occur, making it difficult if not impossible to exercise and enforce rights. Against the background of the current infrastructure, all that can be done is to set in motion a series of bilateral communications from one custodian to the next. That is cumbersome, timeconsuming, costly and prone to mistakes. Investors are unable to claim against or chase anyone but their own custodian. Custodians have reputational incentives. However, since sub-custodians have no relationship with investors and their identity is not known to the investor, their reputation is exposed only to a very limited extent. This makes investments that are associated with custody chains unattractive.

25 Nolan (2003), at p. 81. 


\section{Shortfalls and Regulation}

\subsection{Introduction}

Another problem rendering a market infrastructure built on custody chains inefficient and creating a barrier obstructing cross-border investment is that investors only have full entitlements if all custodians have sufficient balances to meet the claims of all investors concerned. If there is a shortfall at the level of any of the custodians, the rights of the investor are reduced. In a custody chain, the risk of shortfalls is significant. The more custodians, the more likely it is for any of their staff to make a mistake. Also, each custodian has its own IT infrastructure, and connections between different IT systems can be fickle, posing a further inroad for information to be lost.

Shortfalls are not a hypothetical problem. When Bear Stearns was restructured, an excess of $28 \%$ of shares compared to the shares issued by the company was discovered. In the discussion paper justifying the Regulation on central securities depositories the European Commission writes: 'Fortunately, Bear Stearns was rescued through a takeover by JP Morgan which bailed out the excess of securities. ${ }^{26}$ In reality this means, of course, that the price JP Morgan was prepared to pay was distributed between all indirect investors, diluting each of their shares.

The law attempts to reduce the risk of shortfalls by way of regulation. The regulatory approach to custody differs from the approach to banking. Depositholding customers of banks have contractual claims. The regulatory aim is to ensure that a bank will, at all times and on short notice, be able to satisfy these claims. The focus of regulation is on financial stability and capital requirements. ${ }^{27}$

Clients of custodians have proprietary rights in the assets held for them. In the event of the custodian's insolvency, their rights are unaffected by the claims of the custodian's creditors. However, these rights only exist if the custodian and all sub-custodians have set aside assets for clients. If there are no assets, there are no property rights. The regulatory aim is to ensure that custodians have sufficient assets for proprietary rights to exist. ${ }^{28}$

The focus is on asset segregation. Following the 2008 financial crises, the European Union has put significant effort into improving the regulatory regime. The backbone of the European regime consists of MiFID and the MiFID Implementing Directive (MiFID ID). ${ }^{29}$ The European Union recently adopted a new version of MiFID (MiFID 2) ${ }^{30}$ On 19 December 2014, ESMA delivered its Technical Advice

\footnotetext{
${ }^{26}$ Commission Staff Working Document: Impact Assessment accompanying the document Proposal for a Regulation of the European Parliament and of the Council on improving securities settlement in the European Union and on central securities depositories (CSDs) and amending Directive 98/26/EC, SWD/ 2012/0022-COD 2012/0029, para. 8.9 (Annex 9).

${ }^{27}$ Staikouras (2014), at pp. 104-106.

28 Ibid., at pp. 105-107.

${ }^{29}$ Directive 2006/73/EC, OJ 2006 L 241 of 2 September 2006.

${ }^{30}$ Directive (EU) No 65/2014/EU of the European Council of 15 May 2014 on markets in financial instruments and amending Directive 2002/92/EU and Directive 2011/61/EU (recast), OJ 2014 L 173 of 12 June 2014; Regulation (EU) No 600/2014 of the European Parliament and of the Council of 15 May 2014 on markets in financial instruments and amending Regulation (EU) No 648/2012, OJ 2012 L 201 of 27 July 2012.
} 
on implementing measures following from the MiFID 2 regime. ${ }^{31}$ In due course, this will lead to an updated version of the MiFID Implementing Directive.

In May 2014, the EU adopted a Regulation on central securities depositories. ${ }^{32}$ There are special as well as recently updated requirements for depositories of alternative investment funds (AIFs) ${ }^{33}$ and undertakings for the collective investment of transferable securities (UCITS). ${ }^{34}$

It will be shown below that the regulatory regime is unlikely to significantly reduce the risk of shortfalls and to enhance the efficiency of the current market infrastructure.

\subsection{Outsourcing of Custody}

The regulatory regime explicitly permits outsourcing. ${ }^{35}$ The third party needs to be subject to regulation and there are requirements as to how outsourcing is to be identified and monitored. ${ }^{36}$

Depositories of AIFs and UCITS are permitted to delegate the safekeeping of assets if they can demonstrate that there is an objective reason for the delegation and there is no intention of avoiding the regulatory requirements. ${ }^{37}$ The Regulation provides no further explanation of what constitutes an objective reason but the fact that sub-custodians offer an attractive price would very likely qualify as an objective reason justifying the delegation. There is also no limit on the length a custody chain can reach.

Even central securities depositories are allowed to outsource. This is subject to conditions that are designed to preserve the responsibility of the CSD and assist with regulatory oversight. ${ }^{38}$ The outsourcing of core services, for example, is subject to regulatory approval. ${ }^{39}$ The reason justifying outsourcing by CSDs is to facilitate the creation of links between CSDs. Links can allow investors to access new markets.

\footnotetext{
31 ESMA/2014/1569 (ESMA Technical Advice).

32 Regulation (EU) No 909/2014.

33 Directive 2011/61/EU of the European Parliament and of the Council of 8 June 2011 on alternative investment fund managers and amending Directive 2003/41/EC and 2009/65/EC and Regulations (EC) No 1060/2009 and (EU) No 1095/2010 (AIFM Directive), and Commission Delegated Regulation (EU) No 231/2013 of 19 December 2012 supplementing Directive 2011/61/EU of the European Parliament and of the Council with regard to exemptions, general operating conditions, depositories, leverage, transparency and supervision (AIFM Regulation).

34 Directive 2009/65/EC of the European Parliament and of the Council of 13 July 2009 on the coordination of laws, regulations and administrative provisions relating to undertakings for collective investment in transferable securities, last amended by Directive 2014/91/EU of 23 July 2014 (UCITS Directive).

35 MiFID ID, Art. 17(1).

36 MiFID ID, Art. 17(1)-(3); see also ESMA Technical Advice, supra n. 31, at p. 77, paras. 17 and 18.

37 AIFM Directive, Art. 21(11); Recital 39 of the AIFM Directive stresses that delegation and subdelegation 'should' be objectively justified; UCITS Directive, Art. 22a(2), and UCITS Directive 2014/91/ EU, Recitals 20 and 23.

38 Central Securities Depositories Regulation, Regulation (EU) No 909/2014 (CSDR), Recital 34 and Arts. 30-31.

39 Ibid., Recital 28 and Art. 30(4). Core services are listed in CSDR Art. 19(1).
} 
The flip side of using outsourcing as a method to create such links is, however, that an additional level is created. This complicates the system even further and makes it difficult for an efficient infrastructure to emerge.

\subsection{Asset Segregation in a Custody Chain}

MiFID 2 requires firms that hold financial instruments belonging to clients to make adequate arrangements so as to safeguard the ownership rights of clients, especially in the event of the firm's insolvency, and to prevent the use of a client's financial instruments on own account other than with the client's express consent. ${ }^{40}$ Client assets must be identifiable 'by means of differently titled accounts on the books of the third party'. ${ }^{4}$

The requirement for identifiability 'on the books of the third party' has received a wide interpretation on the EU's official question-and-answer forum. According to this forum, a custodian would not be in compliance with MiFID rules if its subcustodian simply facilitated the segregation of client assets in its own internal system and held the assets with the next sub-custodian in its own name. ${ }^{42}$

To comply with client asset rules, a firm must require its sub-custodian to do two things:

1. The sub-custodian must keep three types of internal accounts: one for the custodian's clients, one for the custodian's own proprietary holdings, and one for its own proprietary holding.

2. In addition, a custodian needs to secure a promise from its sub-custodian to maintain three types of separate accounts with their external provider: one for clients of the custodian employing the sub-custodian, one for the custodian's own proprietary assets, and one for the sub-custodian's own proprietary assets.

It would seem that, beyond that, a custodian has no obligation to ensure external segregation. In particular, it would appear that the custodian does not have an obligation to require its sub-custodian to keep separate accounts titled with the names of the custodian's clients or even beyond that, to cause the sub-custodian of the sub-custodian to keep separate accounts associated with the names of the clients of the custodian.

Moreover, it would seem possible that client assets are mixed with proprietary assets of further sub-custodians. Because there is no limit on further delegation and because the asset separation rules stop after level 3, the rules on separate accounts can be undermined through the addition of sub-custodians to the chain. This can provide an incentive for further delegation. If we assume that custodians that do not need to offer separate accounts or that can use securities in lending arrangements can offer cheaper rates, it becomes attractive for custodians that have to comply with stricter rules to delegate custody to them.

\footnotetext{
40 MiFID 2, Art. 16(8).

41 MiFID ID, Art. 16(1)(d); in order to comply with client separation rules, assets will be held in the name of a nominee company that holds the securities on trust for the sub-custodian. Hainsworth (2007), at p. 12; Manifest (2007), at p. 4; see also van Esch (Robeco), supra n. 14.

42 ID 853: Client funds and client property rules (Internal Reference 278), available at http://ec.europa. eu/finance/koel/index.cfm?fuseaction=domain.show\&did=6 (last accessed 9 Sept 2016).
} 
The rules governing AIFs and UCITS reach further than the MiFID rules. A depository of such a fund 'must ensure' that a third party to whom the depository has delegated functions does not, in turn, sub-delegate those functions unless the delegate complies with the same requirements that apply to the depository. ${ }^{43}$

The AIF/UCITS rules, however, do not specify how a depository is to 'ensure' that restrictions continue to operate beyond the level of its immediate sub-custodian. Presumably, the depository needs to insist on contractual terms reflecting this requirement in the contract with its immediate sub-custodian. However, beyond that, there appears to be no requirement for the depository to request being involved in identifying further sub-custodians or in setting terms at further levels. In addition, there is no requirement for a sub-custodian to investigate restrictions relating to its client. This makes it possible for information on restrictions to disappear as the chain increases in length.

The regime governing AIFs and UCITS is not sufficiently granular to ensure that investor rights are preserved throughout the chain. The rules on asset segregation do not adequately contain the risk of shortfalls arising.

\subsection{Reconciliations in a Custody Chain}

The regulatory regime also tries to contain the risk of shortfalls by requiring reconciliation of records. According to MiFID ID, firms have to carry out internal reconciliations of the safe custody assets held for each client with the safe custody assets held by' the custodian and its sub-custodian. ${ }^{44}$ A firm must also conduct external reconciliations between its internal accounts and those of any third party by whom those safe custody assets are held. ${ }^{45}$

The requirement for reconciliations applies to all levels. There is no requirement for the custodian to verify asset separation beyond the level of its immediate subcustodian. This is problematic because a shortfall at any of the levels of the chain will reduce the assets of the client.

Admittedly, each custodian is subject to its own regulatory regime and this also includes asset segregation rules. However, intermediaries other than the custodian immediately connected with the investor operate on incomplete information. They, their auditors and regulators have no access to the records at the level above them.

The timing of any particular reconciliation process is not synchronised with the timing of the reconciliations carried out at other levels. This makes it possible for shortfalls to remain undetected. The economic loss will fall on the investor. The lack of synchronised reconciliations that are carried out over the whole length of the chain can cause investors to suffer significant loss from shortfalls. ${ }^{46}$ Since it

\footnotetext{
43 See also AIFM Directive, Art. 21(11), penultimate paragraph, and UCITS Directive 2014/91/EU, Art. $22 \mathrm{a}(3)(\mathrm{b})$, last paragraph.

44 MiFID ID, Art. 16(1)(c).

45 Ibid.

46 In the case of Bear Stearns the shortfall was $28 \%$, almost one-third (see supra n. 26).
} 
operates independently at the level of each custodian, the regulatory requirement for reconciliations has limited effect and does not significantly reduce the risk of shortfalls.

\subsection{Limitations of Regulation}

Overall, the current regulatory regime does not adequately address the inefficiencies prevailing in custody chains. It has already been mentioned that the European Commission is investigating if the regulatory regime can be improved. ${ }^{47}$ One avenue would be to reform asset segregation rules. The requirement for separate accounts could be made to operate at all levels, irrespective of how far it stretches. This could be supported by a requirement for synchronised reconciliations. The investor's custodian and its auditor would have to request confirmation that sufficient numbers of securities are held by all custodians forming the chain. This would require the investor's custodian to insist on contractual terms that make it possible to identify further custodians and request confirmation from them in a way that allows them to carry out reconciliations. The arrangement would also have to facilitate verification through auditors. Sub-custodians who are unable to offer such a facility could not be employed by custodians holding client assets.

The current framework only creates an obligation for the custodian delegating custody. It does not require a sub-custodian to carry out checks about the arrangements governing its client. A duty could be imposed on custodians who act for other custodians to participate in reconciliation processes and to request confirmation that the assets they hold in the custodian's own name are not in fact client assets. This would help ensure that shortfalls are detected in a timely fashion and make it easier for restrictions to apply at all levels.

However, this does not help investors who want to claim against issuers. We have already seen that investors could be empowered through mandatory rules enabling them to pierce through the chain, but this only provides a time-consuming and costly remedy, burdening cross-border investment with significant disadvantages. It is next to impossible for the law to make connections effected through custody chains safe and efficient to use.

\section{Target 2 Securities}

In its Green Paper the Commission mentions that some believe that the Target 2 Securities (T2S) project will solve the problems associated with the current infrastructure. The European Central Bank started this project in 2006 to explore the possibility of creating a pan-European service for securities settlement in the euro area. $^{48}$ T2S went live on 22 June 2015 when the first group of central securities depositories started operations on the platform.

\footnotetext{
47 See Sect. 3 above.

${ }^{48}$ For information about the project, see https://www.ecb.europa.eu/paym/t2s/html/index.en.html.
} 
$\mathrm{T} 2 \mathrm{~S}$ is a computer programme for central securities depositories, central banks, custodians and other intermediaries to process transfers and record securities holdings. The focus of the project is on settlement.

It does not allow investors to connect directly with issuers but only serves custodians connected to a CSD, permitting them to operate according to the same timetable and use the same ISO 20022 messages format.

$\mathrm{T} 2 \mathrm{~S}$ offers custodians a common software. The hope is that this will enable them to move securities more quickly and cheaply between markets, for example, to deliver collateral not presently needed in one market to another market where it is needed. T2S is supported by the CSD Regulation, which aims to abolish national monopolies, thus giving custodians and CSDs the opportunity to operate in all European markets. $^{49}$

It is hoped that the combined effect of a common IT platform connecting custodians across borders and the abolition of national monopolies will facilitate competition between market participants and, over time, lead to a reduction in the number of CSDs.

This is unlikely to happen. The UK has had law since 1996 that permits more than one CSD to operate within its jurisdiction. ${ }^{50}$ No provider has so far chosen to compete with the incumbent CSD. Instead, Euroclear took over Crest Ltd in 2002. Since then, Crest has been operated by a major global custodian who would be able to actively promote direct holdings also with international clients. Intermediation levels have, however, been unaffected by this.

Only a limited number of custodians operate across borders in Europe. They may not be interested in competing with each other. Making it easier for them to communicate does not provide them with an incentive to compete. It is also unlikely to significantly reduce the length of custody chains. Without a reason to compete, the abolition of national monopolies enables the current global custodians to divide the market between them without reducing the levels of intermediation.

\section{Nature of the Problem}

The contracts connecting custodians are an expression of arrangements as between custodians. The contracts enable them to each organise their respective business in a straightforward way. They benefit from the current structure and its opacity. It enables them to operate services without having to carry out investigations stretching over multiple levels, verifying if investors have approved the arrangements concerned. It also means that the income generated by this activity is unobservable by investors, who, if they were aware, would be justified to review the level of income and its distribution.

Custodians are unlikely to be interested in change. Existing market participants have shown themselves to be strongly committed to protecting the status quo. Two recent examples illustrate this.

\footnotetext{
49 de Vauplane and Yon (2013), at pp. 200-202. See also Iglesias-Rodriguez (2012).

50 Uncertificated Securities Regulation 1995, reg. 4-6 (1995 SI 3272), now contained in Uncertificated Securities Regulation 2001, reg. 4-6 (2001 SI 3755).
} 
When the UK tried to develop an electronic settlement system after the paper crunch in 1987, the London Stock Exchange and its members tried to develop a system that would suit all of their respective needs and interests but failed. Reaching agreement proved impossible. Part of the problem were the vested interests of existing market participants. The London Stock Exchange and its participants spent 7 years and, at that time, some $£ 400$ million trying to set up an electronic settlement system keeping all participants happy. ${ }^{51}$ The developers of the new mechanism tried to achieve the impossible: to create a new system while leaving the role of existing participants intact. On 11 March 1993, the project was abandoned. ${ }^{52}$ The Bank of England took over the reform process and put in place the current settlement system, CREST, which started to operate on 15 July 1996.

Another example of how intense the pressure from existing market participants can be is the UNIDROIT Convention on Substantive Rules for Intermediated Securities (Geneva, 2009). The material available from the UNIDROIT website demonstrates that the working group aimed to identify and remedy legal uncertainty and, after substantial pressure from the industry, delivered an instrument that is not explained by reference to issues of legal certainty and has no impact on existing market participants. ${ }^{53}$

The intermediated structure causes the infrastructure that facilitates investment to be complex at both an operational and a legal level. This complexity is welcome from the perspective of each individual custodian that is able to limit its contractual responsibility to its immediate client. ${ }^{54}$ The problems associated with this complexity do not affect any of the custodians. They are passed on to investors. In addition to the risk associated with the issuer, investors are also exposed to the risk that their assets may be lost in the opaque infrastructure that operates between them and the issuer and that prevents them from claiming against issuers. This may explain why the citizens of Europe are reluctant to put their money in cross-border investments.

\section{Creating Competition}

Recent technological advances have seen the emergence of digital currencies. The same technology might be suitable to create a system that directly connects issuers and investors. For this to happen, however, incentives for competition are required. These can only come from investors. At present, investors only know that their terms allow for the delegation of custody. They do not know if and to whom their assets are outsourced and on what terms. They are also unaware of how long the chain is. Transparency would help to kick-start competition, leading to a more efficient system. Custodians should have to disclose to investors the identity and the terms of all sub-custodians that operate between them and the issuer.

\footnotetext{
51 The Economist, 13 March 1993, p. 119.

52 The Financial Times, 12 March 1993, p. 19.

53 Micheler (2014a); Micheler (2014b), paras. 5.37-5.40.

54 Micheler (2015), at pp. 526-528.
} 
Recent technological advances have made cryptocurrencies possible. IT solutions have been developed that operate without the requirement for a central provider but still allow investors to have a direct relationship with an asset. ${ }^{55}$ The European Union should investigate if the possibilities created by this development could serve the infrastructure for securities.

The existing network of intermediaries was set up using methods created before electronic communication became possible. It makes holding securities cross border expensive and depresses asset values. The problems caused by inserting a custody chain between issuers and investors do not matter much when cross-border holdings are sporadic. However, the issue becomes a matter of discussion and possible reform for the European Union, which has set itself the policy objective of providing a framework which will facilitate a single European market. It seems that an appropriate point has been reached for a policy intervention that facilitates the emergence of an unintermediated settlement and holding mechanism.

Open Access This article is distributed under the terms of the Creative Commons Attribution 4.0 International License (http://creativecommons.org/licenses/by/4.0/), which permits unrestricted use, distribution, and reproduction in any medium, provided you give appropriate credit to the original author(s) and the source, provide a link to the Creative Commons license, and indicate if changes were made.

\section{References}

de Vauplane H, Yon J-P (2013) The concept of integrity in intermediated holding systems. In: Conac PH, Segna U, Thevenoz L (eds) Intermediated securities. Cambridge University Press, Cambridge, pp 200-202

Hainsworth A (2007) The Shareholder Rights Directive and the challenge of re-enfranchising beneficial shareholders. LFMR 1:11

Iglesias-Rodriguez P (2012) The regulation of cross-border clearing and settlement in the European Union from a legitimacy perspective. EBOR 13:441

Kahan M, Rock EB (2007) Hedge funds in corporate governance and corporate control. University of Pennsylvania Law Review 155:1021

Manifest (2007) Safe custody and shareholder rights. The impact of pooled accounts. A Manifest Discussion Paper

Micheler E (2014a) Intermediated securities and legal certainty. LSE Legal Studies Working Paper No. 3/2014. http://papers.ssrn.com/sol3/papers.cfm?abstract_id=2336889. Accessed 27 Sept 2016

Micheler E (2014b) The transfer of intermediated securities and legal certainty. In: Keijser T (ed) Transnational securities law. OUP, paras. 5.37-5.40

Micheler E (2015) Custody chains and asset values. Camb Law J 74:505

Nolan RC (2003) Indirect investors: a greater say in the company? J Corp Law Stud 3:73

Staikouras PK (2014) A novel reasoning of the UK Supreme Court in Lehman Brothers: the MiFID segregation rules from the angle of financial intermediation and regulatory theory. J Bus Law 2:97

Strenger C, Zetzsche D (2013) Corporate governance, cross-border voting and the (draft) principles of the European securities law legislation-enhancing investor engagement through standardisation. JCLS 13:503

Vigna P, Casey MJ (2015) Cryptocurrency: how bitcoin and digital money are challenging the global economic order. The Bodley Head, London

Zetzsche D (2008) Shareholder passivity, cross-border voting and the Shareholder Rights Directive. JCLS $8: 289$

\footnotetext{
55 For a short overview of how the technology underlying cryptocurrencies works, see 'Blockchains', The Economist, 9-15 May 2015, Special Report: International Banking, pp. 15-17; see also Vigna and Casey (2015).
} 